\title{
CONDENSED TANNIN CONCENTRATIONS OF THREE LotuS SPECIES GROWN IN DIFFERENT ENVIRONMENTS
}

\author{
Hernán Acuña ${ }^{1 *}$, Alex Concha ${ }^{2}$, and Marcos Figueroa ${ }^{2}$
}

\begin{abstract}
A B S T R A C T
Condensed tannins (CT) present in Lotus spp., depending on their concentration in the plant, can prevent bloating and improve protein absorption in ruminants. With the objective to know the variability of this characteristic, the CT concentration (\% dry matter basis) was determined by the butanol- $\mathrm{HCl}$ procedure in 13 cultivars of Lotus corniculatus $\mathrm{L}$. (Lc) introduced from North and South America and Oceania, 11 accessions of Lotus tenuis Waldst. \& Kit. ex Willd. (Lt), and 22 accessions of Lotus uliginosus Schkuhr (Lu) collected in Chile, from $32^{\circ}$ to $38^{\circ} \mathrm{S}$ and $36^{\circ}$ to $46^{\circ} \mathrm{S}$, respectively. The field experiments, with two randomized complete blocks, were established in autumn 1998, in five different environments in the central-southern zone of Chile (clay soil, sandy soil, and three volcanic soils with different levels of water availability). The herbage sampling was conducted in spring-summer 1999-2000, when the plants were in full flowering. Significant differences between cultivars or accessions were found within each site, in total CT and/or in extractable or protein or fiber bound fractions of $\mathrm{CT}$ concentrations. The Lc and Lu genotypes showed high variability, with a range of 4.7 to $8.7 \%$ and 6.3 to $11.0 \%$, and means of 6.1 and $8.2 \%$, respectively, of total CT. The Lt general mean was $4.8 \%$, considerably higher than the figures reported in the literature, and had low variability. This information will contribute to select genotypes for the improvement of this species by selection and breeding.
\end{abstract}

Key words: Lotus corniculatus, L. tenuis, $L$ uliginosus, condensed tannins.

\section{INTRODUCTION}

The forage species of the genus Lotus, in particular L. corniculatus $(\mathrm{Lc})$ and L. uliginosus $(\mathrm{Lu})$ and to a lesser measure L. tenuis (Lt), contain condensed tannins (CT) in their tissue. It was observed in the 1960 s that these compounds prevented meteorism in ruminants and a decade later the presence of these compounds was confirmed in Lotus spp. and other forage legumes.

CTs are secondary products of plants, found in cell walls or stored in vacuoles, stems, bark, leaves, flowers or seeds, mainly in dicotyledonous plants. From the chemical point of view, they are complex organic compounds derived from flavonol, soluble in water, with a molecular weight of 500 and 3000 , and are capable of precipitating proteins. McMahon et al. (2000) provides a detailed review about the chemistry of these compounds, their functions and location within plants.

Meteorism in ruminants that consume forage legumes occurs when the gases produced during the fermentation of the food are trapped within the rumen in the form of stable foam. This foam impedes the normal expulsion of gas and thus increases intra-ruminal volume and pressure (Tanner et al., 1995). The forage species of the genus Lotus, which contains an appreciable quantity of CT, does not produce this serious digestive disorder and thus can reduce the incidence of meteorism in animals that consume high risk plants, such as alfalfa (Medicago

\footnotetext{
${ }^{1}$ Instituto de Investigaciones Agropecuarias, Casilla 426, Chillán, Chile.

E mail: hacuna@inia.cl *Corresponding author.

${ }^{2}$ Universidad de Concepción, Facultad de Agronomía, Casilla 537, Chillán, Chile.

Partial results of this work have been presented in: 28th Annual Meeting of the Chilean Society for Animal Production, Talca, Chile, 2003; 20th International Grassland Congress, Ireland and the United Kingdom, Dublin, 2005, and Lotus Newsletter 35(1):11-12, 2005.

Received: 29 November 2006.

Accepted: 1 February 2007.
} 
sativa L.), white clover (Trifolium repens L.) or red clover (Trifolium pratense L.), possibly bonding themselves to the proteins in the ruminal fluids and reducing the capacity to give stability to the foam (McMahon et al., 1999). Low levels of CT in the feed improves the utilization of protein by ruminants without affecting the consumption or the digestibility of carbohydrates (Wang et al., 1996), increasing the flow and absorption of nitrogenated non-ammonia compounds (dietary protein, endogenous and microbial, peptides and amino acids) to the small intestine. This can be of high economic value given that protein is generally the most expensive component of animal feed.

The measurement of CT in a plant is complex owing to its reactivity to other compounds. With neutral $\mathrm{pH}$, condensed tannins form stable compounds with proteins and carbohydrates, reducing their extractability (Terrill et al., 1990). In order to determine total CT in plants, Terrill et al. (1992) proposed a procedure that allows for determining extractable $\mathrm{CT}$, protein bound $\mathrm{CT}$ and fiber bound $\mathrm{CT}$ separately. Much of the information that exists in the literature has been obtained by methods that only determine extractable CT, such as that provided by Kelman (2006). Nevertheless, according to Terrill et al. (1992) there is a good correlation between extractable and total CT. On average, for the 11 forage legumes studied, extractable CT was $68 \%$ of total CT. The aforementioned authors found that $33 \%$ of total CT was extractable in the specific cases of Lc and Lt.

CT concentration in plants is primarily controlled by genetic factors and secondarily by environmental variables (Miller and Ehlke, 1996; McMahon et al., 2000). In general, the concentration increases with the maturity of the plant and is associated with the increase of lignin in the tissue, which can cause a reduction in the digestibility of forage when it reaches excessively high levels. Among the environmental factors, air temperature and the fertility of the soil are the most important. Lees et al. (1994) reported that Lotus pedunculatus Cav. (syn. L. uliginosus) reached higher levels of $\mathrm{CT}$ when it grows at $30^{\circ} \mathrm{C}$ compared to $20^{\circ} \mathrm{C}$, and other authors have observed significantly higher levels of CT in plants that grow in acidic soils with low fertility in comparison to plants cultivated in soils with high fertility. Nevertheless, the application of lime to soil (which raised the $\mathrm{pH}$ level from 4.3 to 5.2) did not significantly reduce $\mathrm{CT}$ concentration in $\mathrm{Lc}, \mathrm{Lu}$, and Lt leaves, maintaining the clear differences among species (Kelman and Tanner, 1990).

The former reinforces the conclusion of Carter et al. (1999), in the sense that the relation between soil fertility and CT concentration in the plant can be confused with the effect of climatic factors, such as hydric stress, temperature, and concentration of carbon dioxide. Anuraga et al. (1993) reported that the level of CT in Lu increased when the rate of growth was reduced by hydric stress and high temperatures, while in Lc these factors did not affect the level of CT. The availability of sulphur in the soil is also important. Kelman (2006) found that CT levels in Lc remained low when the levels of phosphorus and sulphur increased, while in Lu CT levels increased with the increase of available phosphorus and sulphur.

According to the work of Kelman and Tanner (1990), the concentrations of CT in Lc vary between 0.15 and $7.28 \%$, dry matter basis, with an average of 2.09; Terrill et al. (1992) reported 2.1\% of total CT for this species; Anuraga et al. (1993) reported values of between 0.5 and $6 \%$, with a maximum in the summer; Douglas et al. (1999) obtained total CT concentration of $5.0 \%$, of which $2.2 \%$ were protein bound and $0.4 \%$ fiber bound; and Kelman (2006) measured $0.4 \%$ in young plants (68 days). In general, Lc has lower CT concentrations than Lu, with averages close to the range of 2 to $3 \%$, which was suggested as optimal by Waghorn et al. (1990) to improve efficiency in the use of protein without reducing consumption and digestibility. The information from the literature on CT concentrations in $\mathrm{Lu}$ provides measurements in the range of 2.5 to $10.7 \%$ of extractable tannins (Kelman and Tanner, 1990); $10 \%$ for cv. Sharnae and 2 to $5 \%$ for cv. Maku (Anuraga et al., 1993). Of the three species, Lt has the lowest CT content: 0.07 and $0.16 \%$ of extractable CT, with soils without lime treatment and lime-treated soils, respectively, according to Kelman and Tanner (1990), and $0.6 \%$ of total CT according to Terril et al. (1992).

The objective of this work was to determine the variability of CT concentration in germplasm of three species of Lotus, introduced (L. corniculatus) or collected in Chile (L. tenuis and L. uliginosus), cultivated in five environments in the Bio-Bio and Araucanía regions. This information will comple- 
ment the agronomic characterization (Acuña et al., $2002 \mathrm{a} ; 2002 \mathrm{~b})$ and regarding the biological nitrogen fixation (Acuña et al., 2004) of the germplasm studied, to identify which accessions can be used in genetic improvement programs in central and southern Chile.

\section{MATERIALS AND METHODS}

The germplasm studied included 12 cultivars of Lotus corniculatus (Lc) introduced from North America, South America and Oceania, as well as one native cultivar; 11 accessions of Lotus tenuis $(\mathrm{Lt})$ and 21 accessions of Lotus uliginosus (Lu) from collections of naturalized germplasm carried out in Chile, plus the New Zealand cultivar Maku. The source of each of the cultivars of introduced Lc is detailed in Acuña et al. (2002b) and the original identification of the accessions and the location and characteristics of the soil of the collection sites of Lt and $\mathrm{Lu}$ are found in Acuña et al. (2002a).

To determine CT, two replicates of the experiments of agronomic characterization of the aforementioned materials were used. These experiments were carried out between 1998 and 2000, in a complete randomized block design, with four replicates, in five localities, including in each of them the species best adapted to their respective environments. In Chillán (36 $36^{\prime} \mathrm{S} ; 7^{\circ} 02 \mathrm{~W}$ ) and Cabrero (36 $58^{\circ}$ $\left.\mathrm{S} ; 7^{\circ} 23^{\prime} \mathrm{W}\right) \mathrm{Lc}, \mathrm{Lg}$ and $\mathrm{Lu}$ were studied; Lc and $\mathrm{Lg}$ in Cato (36 $\left.32^{\prime} \mathrm{S} ; 71^{\circ} 54^{\prime} \mathrm{W}\right)$; $\mathrm{Lc}$ and $\mathrm{Lu}$ in Vilcún $\left(38^{\circ} 41^{\prime} \mathrm{S} ; 72^{\circ} 25^{\prime} \mathrm{W}\right)$, and Lc in San Ignacio $\left(36^{\circ} 49^{\prime} \mathrm{S} ; 71^{\circ} 55^{\prime} \mathrm{W}\right)$. The form and date of the establishment of the experiments, the size of the plots, the application of fertilizers, irrigation in some localities and the management of cuttings is described in Acuña et al. (2002a) for Lc, and in Acuña et al. (2002b) for Lt and Lu. Table 1 presents the characteristics of soil and climate of each locality.

Analyses of variance were computed in accordance with the design used for the results for each experiment and each variable. The standard error of the mean (s.e.m.) is presented in the tables as an expression of the variability of the germplasm studied and for allowing comparison of means within cultivars or accessions.

\section{Sampling and determination of condensed tannins}

The samples used for the analysis were obtained from the second cutting of the 1999-2000 growing season (November-December for Lc and December-January for $\mathrm{Lt}$ and $\mathrm{Lu}$, depending on the locality), when the plants were in full flowering. The number of days of regrowth (or accumulation) for Lc, counting from the previous cutting, were 38 , 46, 53, 53 and 51, for the localities of Chillán, Cato, Cabrero, San Ignacio and Vilcún, respectively. With $\mathrm{Lt}$, the number of regrowth days was 39, 40 and 43, for the localities of Chillán, Cato and Cabrero, respectively. The number of regrowth days for $\mathrm{Lu}$ was 40, 42 and 41, for the localities of Chillán, Cabrero and Vilcún, respectively. The plants were harvested leaving $5 \mathrm{~cm}$ of stubble.

Complete plants samples of $40 \mathrm{~g}$ of green matter were taken. The samples were put in polyethylene bags and were placed in a thermos with liquid nitrogen to detain the biological processes of the plant. They were then stored in a freezer at $-20{ }^{\circ} \mathrm{C}$. Subsequently, the samples were dried in a lyophylizer de $6 \mathrm{~L}$ (FreeZone 77530, Labconco Corporation, Kansas City, Missouri, USA). Once they were dried, the samples were ground (sieve $1 \mathrm{~mm}$ ) to determine CT using the butanol-HCL method described by Terrill et al. (1992).

Standards of purified tannin were used, for the extraction and purification of which the procedure described by Terrill et al. (1992) was followed. The wavelength that produced the greatest absorbance was $409 \mathrm{~nm}$, and this was selected to measure the absorbance of a concentrated solution of $600 \mathrm{mg} \mathrm{L}^{-1}$ of purified tannins in a spectrophotometer. To obtain the standard curve, new solutions were prepared of distinct concentrations of tannins, between 600 and $200 \mathrm{mg} \mathrm{L}^{-1}$, based on a concentrated solution. These solutions were read by the chosen wavelength of $409 \mathrm{~nm}$. The data obtained allowed for establishing the regression equation $\mathrm{y}=0.0036 \mathrm{x}-$ $0.0305\left(R^{2}=0.994\right)$, where $y=$ absorbance and $x=$ the concentration of tannins. The results are expressed as a percentage of CT dry matter basis.

\section{RESULTS AND DISCUSSION}

\section{L. corniculatus}

Table 2 presents the CT concentrations of the Lc cultivars from the five sites. As well, the source of each cultivar is indicated, which does not necessarily correspond to the obtainer.

In the locality of Chillán, cv. Ges-5 had a lower concentration of extractable CT $(\mathrm{P}<0.05)$ than 'Geor- 
Table 1. Physical and chemical characteristics of soil and climatic variables per locality.

\begin{tabular}{|c|c|c|c|c|c|}
\hline Item & Cato & Cabrero & Chillán & San Ignacio & Vilcún \\
\hline $\mathrm{pH}$ & 6.00 & 6.80 & 6.50 & 5.90 & 5.70 \\
\hline $\mathrm{OM}, \%$ & 10.00 & 8.10 & 2.50 & 15.00 & 15.00 \\
\hline $\mathrm{N}, \mathrm{mg} \mathrm{kg}^{-1}$ & 21.00 & 11.00 & 9.00 & 16.00 & 35.00 \\
\hline $\mathrm{P}, \mathrm{mg} \mathrm{kg}^{-1}$ & 6.00 & 10.00 & 3.00 & 7.00 & 18.00 \\
\hline $\mathrm{K}, \mathrm{cmol} \mathrm{kg}^{-1}$ & 0.23 & 0.16 & 0.09 & 0.11 & 0.70 \\
\hline $\mathrm{Ca}, \mathrm{cmol} \mathrm{kg}^{-1}$ & 4.60 & 8.86 & 1.32 & 4.77 & 5.60 \\
\hline $\mathrm{Mg}, \mathrm{cmol} \mathrm{\textrm {kg } ^ { - 1 }}$ & 0.56 & 5.39 & 1.10 & 0.48 & 0.73 \\
\hline $\mathrm{Na}, \mathrm{cmol} \mathrm{kg}^{-1}$ & 0.17 & 0.46 & 0.13 & 0.21 & 0.91 \\
\hline $\mathrm{Zn}, \mathrm{mg} \mathrm{kg}^{-1}$ & 0.11 & 0.56 & 0.32 & 0.22 & n.o. \\
\hline $\mathrm{Fe}, \mathrm{mg} \mathrm{kg}^{-1}$ & 30.89 & 67.87 & 41.27 & 25.77 & n.o. \\
\hline $\mathrm{Cu}, \mathrm{mg} \mathrm{kg}^{-1}$ & 0.91 & 3.31 & 1.15 & 0.72 & n.o. \\
\hline $\mathrm{Mn}, \mathrm{mg} \mathrm{kg}^{-1}$ & 2.54 & 33.31 & 3.36 & 1.70 & n.o. \\
\hline $\mathrm{S}, \mathrm{mg} \mathrm{kg}^{-1}$ & 12.00 & 5.00 & 3.00 & 6.00 & n.o. \\
\hline Total depth, cm & 140 & 70 & +100 & +100 & 65 \\
\hline Horizon A depth, cm & 25 & 17 & 23 & 15 & 23 \\
\hline Horizon A texture & $\mathrm{S} \mathrm{Cl}$ fine & $\mathrm{S}$ Sa fine & $\mathrm{Cl}$ & S loamy & S \\
\hline Horizon A porosity, \% & 58 & 47 & 52 & 68 & n.o. \\
\hline Drainage & Moderate & Imperfect & Poor & Good & Good \\
\hline Horizon A bulk density, $\mathrm{g} \mathrm{cm}^{-3}$ & 1.12 & 1.40 & 1.26 & 0.85 & 0.79 \\
\hline Topography & Flat & Rolling & Flat & Slightly hilly & Flat \\
\hline Series & Arrayán & Arenales & Quella & Sta. Bárbara & Vilcún \\
\hline Major group (USDA, 1994) & Melanoxerands & Xeropsamments & s Durixererts & Haploxerands & Melanudands \\
\hline Annual average precipitation, $\mathrm{mm}$ & 1200 & 1100 & 1000 & 1400 & 1400 \\
\hline Months without rainfall & 4 & 5 & 5 & 3 & 2 \\
\hline
\end{tabular}

Source: Soil Laboratory and Meteorological Stations, Instituto de Investigaciones Agropecuarias, Quilamapu Regional Research Center, Chillán.

Sampling for chemical analysis 0-30 cm depth.

OM: organic material; S: silty; Cl: clay; Sa: sandy; n.o.: not observed.

gia-1'; the rest of the cultivars did not differ among themselves. 'AU Dewey' had a significantly higher concentration of protein bound CT $(\mathrm{P}<0.05)$ than all the other cultivars except 'Quimey'. Differences were not found $(\mathrm{P}>0.05)$ in the concentration of fiber bound $\mathrm{CT}$, and the concentration of total $\mathrm{CT}$ in 'AU Dewey' was higher $(\mathrm{P}<0.05)$ than 'Dawn', 'Ganador', 'Ges-5', 'Norcen', 'San Gabriel' and 'Viking', and statistically similar to the rest of the cultivars.

In the locality of Cato there were not significant differences $(\mathrm{P}>0.05)$ among cultivars in extractable $\mathrm{CT}$, but there were $(\mathrm{P}<0.001)$ in protein bound $\mathrm{CT}$, highlighting the high values of 'Steadfast', 'Ganador' and 'Upstart' versus the low level of 'San Gabriel'. The concentration of fiber bound CT in cvs. Dawn and San Gabriel was significantly higher than in cv. Steadfast. There were no significant differences $(P>0.05)$ among the cultivars in total $C T$. In
Cabrero, 'Quimey' had a significantly higher level of extractable CT $(\mathrm{P}>0.05)$ than 'Upstart' and 'Norcen'. The concentration of protein bound $\mathrm{CT}$ in $\mathrm{cv}$. Ganador was significantly higher $(\mathrm{P}<0.01)$ than all the other cultivars, except 'San Gabriel', 'Georgia-1' and 'AU Dewey'. There were no differences $(\mathrm{P}>$ 0.05 ) among the cultivars in concentration of fiber bound and total CT. In San Ignacio, the level of extractable CT in cv. Dawn was statistically higher (P $<0.05$ ) than those of cvs. 'AU Dewey','Georgia-1', 'Ges-5', 'Quimey' and 'Upstart', and did not differ from the rest of the cultivars. There were no significant differences among the cultivars in concentrations of protein bound $\mathrm{CT}$.

The concentration of fiber bound CT of 'Norcen' was higher $(\mathrm{P}<0.05)$ than those of 'Dawn', 'Ganador', 'Granger' and 'Quimey'. The level of total CT of cv. 'Dawn' was higher $(\mathrm{P}<0,05)$ than those of cvs. 'AU Dewey' and 'Georgia-1'. Finally, in the 


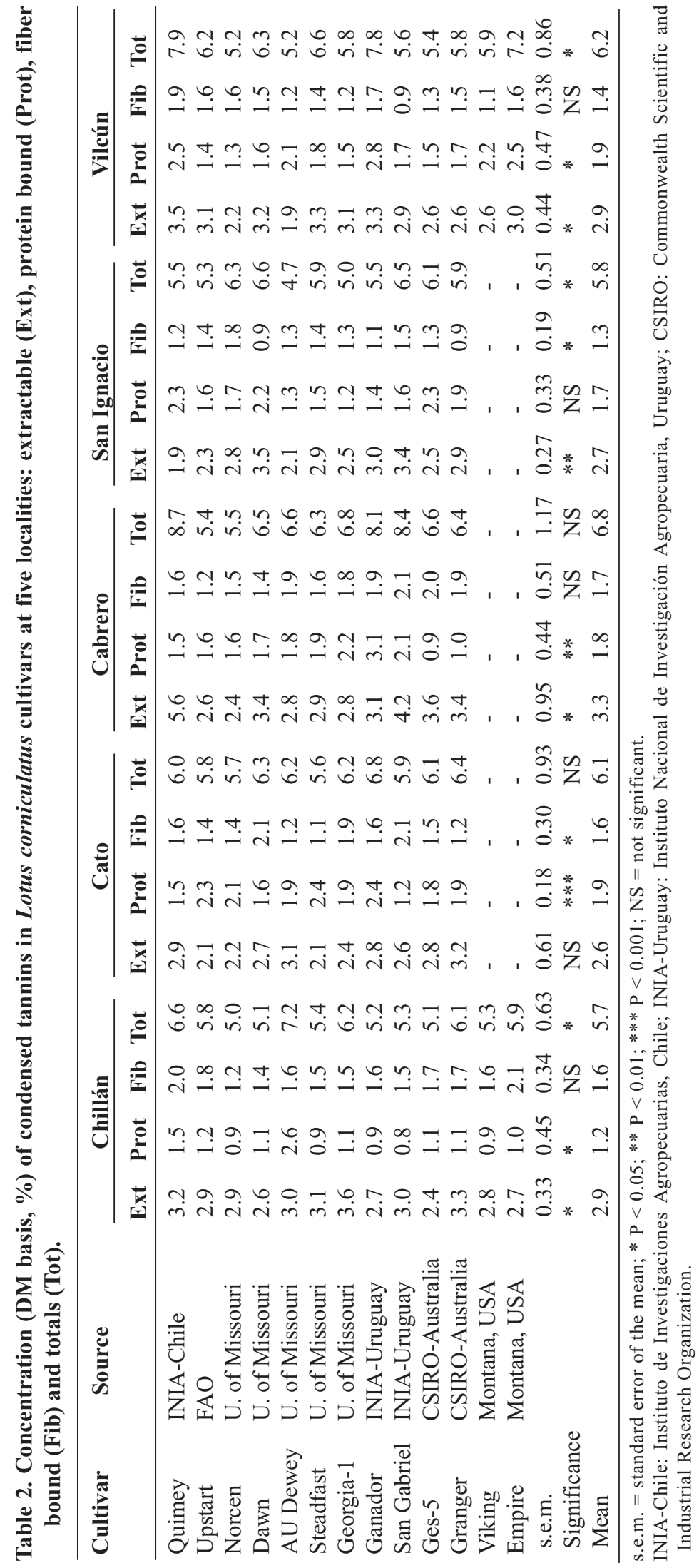


locality of Vilcún, the concentration of extractable $\mathrm{CT}$ of 'AU Dewey' was significantly lower $(\mathrm{P}<$ $0.05)$ than 'Quimey', and the concentration of protein bound CT of "Ganador' was higher $(\mathrm{P}<0.05)$ than that of 'Norcen'. There were no significant differences among cultivars in the concentrations of CT fiber bound. Total CT concentration of 'Quimey' was higher $(\mathrm{P}<0.05)$ than 'AU Dewey'.

The results show a high variability in the germplasm of Lc. However, it is less than what has been observed by other authors. Working with 22 accessions in soil with and without lime application, which produced variations in $\mathrm{pH}$ in a range similar to that of the localities studied, but approximately one point lower (4.3-5.2 vs. 5.7-6.8) which did not significantly affect CT content, Kelman and Tanner (1990) obtained a range of extractable CT concentrations of $0.15-7.28 \%$, while in these experiments it was $1.9-5.6 \%$, although the average was higher (2.88 vs. $2.09 \%)$.

In the specific case of cv. Quimey, these authors obtained a lower average ( 2.47 vs. $3.42 \%)$ but with 'AU Dewey' the situation was reversed (3.37 vs. $2.58 \%$ ). This is explained by analytical differences and the fact that in the case of Kelman and Tanner (1990) only leaves were used, while in our experiment, leaves and stems in what was probably a more advanced state of maturity were used. The values of extractable and total CT obtained in this experiment are high compared to those measured by Terrill et al. (1992) for this species, owing that the last ones (0.7 and 2.1, respectively) come from fresh leaves and stems sampled in spring. In general, the results are consistent with those of Anuraga et al. (1993) and Douglas et al. (1999). These last authors reported that the percentage of extractable CT in relation to the total percentage was $52 \%$. In our experiments, the percentage reached a value very close to this, $53 \%$ on average for the 13 cultivars. In both cases, it exceeded the $33 \%$ found by Terrill et al. (1992) for this species in particular, probably due to the earlier phenological state of the foliage analyzed, assuming that the lower the CT content, the greater the proportion is bound to protein or fiber. The concentrations found, in general, slightly exceed the range of 2 to $3 \%$ proposed by Waghorn et al. (1990) or the limit of $4 \%$ of total CT mentioned by other authors, under which level it does not negatively affect the digestibility and the consumption of forage.
The number of days of regrowth, counting from the previous cutting to the date of taking the sampling for analysis, was approximately 5 weeks for Chi1lán, 6 weeks for Cato and 7 weeks for Cabrero, San Ignacio and Vilcún, and the sampling dates of November 17, November 26, December 6, November 27, and November 25, respectively, show a close agreement with the measurements of total CT content of this species per locality: 5,$7 ; 6,1 ; 6,8 ; 5,8$ and 6,2, respectively. Thus from Chillán to Cato, two localities near each other, and consequently with minimal differences in temperature and humidity, an increase was seen owing to the sum of the effects of going from 5 to 6 weeks of regrowth and delay cutting by 9 days. There is then a rise in Cabrero upon going to 7 weeks of regrowth and delaying cutting by 16 more days. Finally, the small decline in CT in San Ignacio and Vilcún was due to the earlier cutting, and the fact that these localities, because of their geographic locations (higher altitude in San Ignacio and higher latitude in the case of Vilcún) (Table 1), have colder and more humid weather in the spring, which determined that the plant maturity was less advanced than in Cabrero, where the soil, because of its sandy texture, losses moisture early in the spring, which, together with the predominance of higher temperatures, determines an acceleration of the maturity process (Anuraga et al.,1993). Despite the proceeding point, it is possible that the material was over-mature in all the cases from the point of view of the recommended management for using in grazing or cutting, which seeks to maximize the quality of forage.

Acuña and Cuevas (1999) reported that a frequency of 6 weeks maximizes the production of forage, but this does not mean that it maximizes its quality from the point of view of CT content. Abarca (1997) found that the velocity of disappearance of dry material, lignin and acid detergent fiber in the rumen, was less in the material harvested with a cutting frequency of 7 weeks to a height of $10 \mathrm{~cm}$ in comparison to harvesting with a frequency of 5 weeks and a height of $2.5 \mathrm{~cm}$, owing apparently to a lower CT concentration in less lignified material.

Upon comparing the averages of each locality in relation to $\mathrm{pH}$ and the availability of phosphorus in the soil (Table 1), these results do not confirm what was reported by Barry and Forss (1983) in the sense that the acidity of the soil and low fertility increase the CT content of the plants. Rather, it confirms 
what was observed by Kelman and Tanner (1990) and Kelman (2006) with regard to the response of $\mathrm{Lc}$ to these factors. Considering that in general $\mathrm{pH}$ fluctuated in a range of values slightly acidic and $\mathrm{P}$ contents were low to medium, except in the locality of Vilcún, the variations respond to hydric stress and temperatures rather than soil conditions, according to what was argued by Anuraga et al. (1993). The clear differences in the relative behavior of the cultivars studied within each locality confirm that there is genetic variability, and that this, in accord with Miller and Ehlke (1996) and McMahon et al. (2000), primarily controls CT concentration in the plants. Marshall et al. (2005) and Marley et al. (2006) studying 7 and 13 cultivars of Lc, respectively, concluded that there is variability between cultivars and within cultivars.

\section{L. tenuis}

CT concentrations in 11 accessions of $\mathrm{Lt}$ in the three localities in which this species was studied are presented in Table 3. In the locality of Chillán, the concentration of extractable CT for the accession Lt4 was higher $(\mathrm{P}<0.05)$ than those of Lt11 and Lt12; the remaining accessions did not differ among themselves. The protein bound CT levels of Lt3 and Lt7 were significantly higher than Lt1, Lt4, Lt12 and Lt14. The fiber bound CT concentration of the accession Lt4 was lower $(\mathrm{P}<0.05)$ than that of Lt14. In Cato, extractable CT from the accession Lt4 was higher $(\mathrm{P}<0.05)$ than the other accessions, except Lt6, Lt8, and Lt 15. Protein bound CT of the accession Lt 15 presented a statistically higher level than the accessions Lt7, Lt8, Lt11 and Lt14. Significant differences were not found $(\mathrm{P}>0.05)$ among the accessions in total $\mathrm{CT}$ concentrations or concentrations linked to fiber. In Cabrero, there were no differences $(\mathrm{P}>0.05)$ among accessions in $\mathrm{CT}$ concentration in any of the fractions or in total.

The CT concentrations of Lt were lower than those of Lc, as was indicated in the literature, but much higher than what was reported by Kelman and Tanner (1990), Terrill et al. (1992) and Douglas et al. (1999), owing in great measure to the fact that these authors used less lignified tissues. The material used in this experiment was in full flowering, sampled 39, 40 and 43 days after cutting in Chillán, Cato y Cabrero, respectively, during summer with dry and hot weather and high level of luminosity (December 29, 1999, January 5, 2000, and January 15,2000 , respectively). This last factor can be of great importance, given that, according to Arcioni et al. (2005), it positively affects the synthesis of CT through the action of the dihydroflavonol reductase enzyme (DFR) regulated by light. All of these anterior could be the reasons for the high CT concentrations found in this species. The references from the literature in this regard, apart from those already cited, are very scarce.

Estrella and Ugalde (1993) did not detect CT in leaves of Lt and stated that the concentration in stems and roots would be lower to be detected by the photochemical procedures usually employed for this purpose, but that the species is capable of synthesizing it.

Strittmatter et al. (1994) analyzed fresh roots, stems and leaves and detected the absence of CT in leaves, presence in stems, and abundance in roots. In this experiment, the range of variation considering the three localities was 3,9-6,6 for total CT and 2,04,6 for extractable CT. The variability found would be very low, given that there were no significant differences among accessions in total CT in any locality, even when the accession Lt4 presented a concentration of extractable CT that was significantly higher than the other accessions in Cato and Chillán.

In the area where these accessions were collected $\left(32^{\circ}\right.$ and $38^{\circ}$ lat. S) edaphic differences are the most notable environmental changes, clay soils with poor drainage, sandy soils with a high phreatic level and silt-loam soils derived from volcanic ash (Acuña et al., 2002b), which has probably not contributed to modify the genotypes of the naturalized populations from the different sites in terms of CT concentration in the foliage. The experience of researchers and farmers in this zone indicates that this species, as in the case of $\mathrm{Lc}$ and $\mathrm{Lu}$, does not produce meteorism in cattle, which would not be explainable if the CT concentrations in the forage were as low as has been reported in the literature. Such levels would not be clearly higher than those found in white clover cv. Huia, $0.25 \%$ (Burggraaf et al., 2005), a high risk plant from this point of view, nor does it exceed the threshold of $0.5 \%$ required according to Li et al. (1996) to avoid meteorism.

\section{L. uliginosus}

CT concentrations in accessions of $\mathrm{Lu}$ for the three localities where the species was studied are pre- 
Table 3. Concentration (DM basis, \%) of condensed tannins in Lotus tenuis accessions at three localities: extractable (Ext), protein bound (Prot), fiber bound (Fib) and total (Tot).

\begin{tabular}{|c|c|c|c|c|c|c|c|c|c|c|c|c|c|}
\hline \multirow[t]{2}{*}{ Accesion } & \multirow[t]{2}{*}{ Source } & \multicolumn{4}{|c|}{ Chillán } & \multicolumn{4}{|c|}{ Cato } & \multicolumn{4}{|c|}{ Cabrero } \\
\hline & & Ext & Prot & Fib & Tot & Ext & Prot & Fib & Tot & Ext & Prot & Fib & Tot \\
\hline Lt1 & Cabrero & 2.3 & 0.7 & 1.2 & 4.2 & 2.4 & 1.6 & 1.1 & 5.1 & 3.1 & 0.9 & 1.4 & 5.4 \\
\hline Lt3 & Yumbel & 2.5 & 1.1 & 1.3 & 4.9 & 2.9 & 1.7 & 1.2 & 5.7 & 2.8 & 1.1 & 1.3 & 5.2 \\
\hline Lt4 & San Javier & 2.7 & 0.6 & 0.7 & 4.1 & 4.6 & 0.9 & 0.9 & 6.6 & 2.7 & 0.9 & 1.9 & 5.5 \\
\hline Lt5 & Parral & 2.3 & 0.9 & 1.3 & 4.5 & 2.1 & 1.5 & 1.1 & 4.7 & 2.2 & 0.8 & 1.0 & 4.0 \\
\hline Lt6 & Parral & 2.4 & 0.9 & 1.2 & 4.5 & 3.2 & 1.5 & 0.8 & 5.5 & 2.4 & 1.2 & 1.6 & 5.2 \\
\hline $\mathrm{Lt} 7$ & Cato & 2.5 & 1.1 & 1.5 & 5.1 & 2.4 & 1.4 & 0.7 & 4.4 & 2.5 & 0.9 & 1.1 & 4.6 \\
\hline $\mathrm{Lt} 8$ & Coihueco & 2.4 & 0.9 & 1.4 & 4.7 & 3.3 & 1.4 & 0.9 & 5.7 & 2.1 & 0.9 & 0.9 & 3.9 \\
\hline Lt11 & Itahue & 2.1 & 0.8 & 1.1 & 3.9 & 2.8 & 1.3 & 0.8 & 4.9 & 2.4 & 0.8 & 0.8 & 4.0 \\
\hline $\mathrm{Lt} 12$ & Villa Alegre & 2.1 & 0.7 & 1.0 & 3.9 & 2.0 & 1.7 & 1.1 & 4.8 & 2.6 & 0.9 & 1.4 & 4.9 \\
\hline Lt14 & Melipilla & 2.4 & 0.7 & 1.6 & 4.7 & 2.8 & 1.2 & 0.9 & 4.9 & 2.2 & 0.9 & 1.3 & 4.5 \\
\hline Lt15 & Las Cabras & 2.5 & 0.8 & 0.8 & 4.1 & 3.0 & 2.1 & 1.2 & 6.3 & 2.2 & 0.8 & 0.9 & 4.0 \\
\hline \multicolumn{2}{|c|}{ s.e.m. } & 0.18 & 0.12 & 0.27 & 0.50 & 0.54 & 0.22 & 0.26 & 0.73 & 0.3 & 0.19 & 0.37 & 0.81 \\
\hline \multicolumn{2}{|c|}{ Significance } & $*$ & $*$ & $*$ & NS & $* *$ & $* *$ & NS & NS & NS & NS & NS & NS \\
\hline \multicolumn{2}{|c|}{ Mean } & 2.4 & 0.8 & 1.2 & 4.4 & 2.9 & 1.5 & 0.9 & 5.3 & 2.5 & 0.9 & 1.2 & 4.7 \\
\hline
\end{tabular}

s.e.m. $=$ standard error of the mean; $* \mathrm{P}<0.05 ; * * \mathrm{P}<0.01 ; * * * \mathrm{P}<0.001 ; \mathrm{NS}=$ not significant.

sented in Table 4. Extractable CT concentrations in the locality of Chillán show that Lu23 differs significantly $(\mathrm{P}<0.05)$ from the accessions Lu9, Lu12, LuP32, LuP48 and LuP58. Protein bound $\mathrm{CT}$ concentrations did not differ significantly $(\mathrm{P}$ $>0,05)$ among accessions, except between LuP4 $(1.3 \%)$ and LuP48 (1.9\%). The fiber bound CT concentration did not differ $(\mathrm{P}>0.05)$ among accessions, and total CT concentration was higher $(\mathrm{P}<0.05)$ in the accession Lu10 than in the accessions Lu9, Lu12 and LuP32. In Cabrero the concentration of extractable CT of the accession LuP58 was higher $(\mathrm{P}<0.05)$ than those of the accessions Lu1, Lu4, Lu8, Lu9, Lu11 and LuP23. No significant differences were found among the accessions in the concentration of protein bound $\mathrm{CT}$, while with fiber bound $\mathrm{CT}$, the concentration of the accession LuP48 was statistically equal (P $>0.05)$ to the accessions Lu2, Lu3, Lu9, LuP4, LuP11, and LuP54 and higher $(\mathrm{P}<0.05)$ than the other accessions. Total CT concentration of the accession Lu2 was higher $(\mathrm{P}<0.05)$ than the concentrations of the accessions Lu1, Lu4, Lu10, Lu11, LuP23, LuP52 and LuP63. There were no differences in Vilcún $(\mathrm{P}>0.05)$ among the accessions in extractable CT concentration and the level of protein bound $\mathrm{CT}$ of the accession Lu5 was higher $(\mathrm{P}<0.05)$ than those of the other accessions studied. The level of fiber bound CT of the accession Lu2 was statistically higher than that of the accessions Lu12, LuP23, LuP36, LuP52,
LuP58, LuP63 and Maku. Total CT concentration of the accession Lu5 was higher $(\mathrm{P}<0.05)$ than those of the accessions LuP48 and LuP52.

The results of Lu show higher levels of CT than found in Lc. The ranges of variation for extractable and total CT from the three localities were 2,66,5 and 6,3-11,0, respectively. Kelman and Tanner (1990), who worked with 11 genotypes of this species, with and without lime application to soil, obtained a mean value for extractable CT lower than those of these experiments $(5.99 \%)$ and a wider range (2.52-10.72\%), which would be evidence of a lower variability in germplasm under study. In the case of cv. Maku, these authors found a mean value greater than that of this experiment (4.8 vs. 5.2), and for the tested Chilean accessions, they obtained an average slightly less than that of the three localities studied (4.5 vs. 4.2). Anuraga et al. (1993) found concentrations of 2.0 and $5.5 \%$ for 'Maku' and between 2.0 and $10.0 \%$ for cv. Sharnee, with variations directly related to temperature, such that the highest values were obtained in summer, a factor which also probably affects the results of this experiment. Despite the variability observed in total $\mathrm{CT}$ concentration among the accessions in the three localities, the lowest values are above the acceptable limits from the point of view of the nutritional quality of the forage (Barry, 1989 ; Waghorn et al., 1990). This does not reduce the utility of this species, given 
Table 4. Concentration (\% of DM basis) of condensed tannins in Lotus uliginosus accessions at three localities: extractable (Ext), protein bound (Prot), fiber bound (Fib) and total (Tot).

\begin{tabular}{|c|c|c|c|c|c|c|c|c|c|c|c|c|c|}
\hline \multirow[t]{2}{*}{ Accession } & \multirow[t]{2}{*}{ Source } & \multicolumn{4}{|c|}{ Chillán } & \multicolumn{4}{|c|}{ Cabrero } & \multicolumn{4}{|c|}{ Vilcún } \\
\hline & & Ext & Prot & Fib & Tot & Ext & Prot & Fib & Tot & Ext & Prot & Fib & Tot \\
\hline $\mathrm{Maku}^{1}$ & New Zealand & 4.5 & 1.7 & 1.8 & 7.9 & 6.1 & 2.4 & 1.4 & 9.9 & 3.8 & 2.0 & 0.9 & 6.8 \\
\hline Lu1 & Piedra Azul & 3.9 & 1.6 & 2.5 & 8.0 & 4.2 & 1.9 & 1.3 & 7.4 & 4.9 & 2.2 & 1.5 & 8.6 \\
\hline $\mathrm{Lu} 2$ & C. Puelche & 4.6 & 1.6 & 2.3 & 8.5 & 6.3 & 2.8 & 1.9 & 11.0 & 3.5 & 2.3 & 2.5 & 8.3 \\
\hline Lu3 & Contao & 4.5 & 1.5 & 2.2 & 8.2 & 4.9 & 1.9 & 1.9 & 8.7 & 5.6 & 1.7 & 1.7 & 9.0 \\
\hline Lu4 & Hornopiren & 5.1 & 1.6 & 2.0 & 8.7 & 3.7 & 2.1 & 1.7 & 7.5 & 4.6 & 2.1 & 1.4 & 8.1 \\
\hline Lu5 & Chaitén & 3.8 & 1.8 & 2.4 & 7.9 & 4.8 & 2.4 & 1.5 & 8.7 & 4.5 & 3.9 & 1.6 & 9.9 \\
\hline $\mathrm{Lu} 7$ & Chaitén & 4.9 & 1.8 & 1.9 & 8.6 & 4.8 & 2.2 & 1.4 & 8.3 & 4.2 & 1.8 & 2.4 & 8.4 \\
\hline Lu8 & Chaitén & 4.2 & 1.7 & 2.4 & 8.4 & 4.1 & 2.5 & 1.5 & 8.1 & .9 & 2.3 & 2.4 & .6 \\
\hline Lu9 & La Junta & & 1.6 & 1.6 & 6.7 & 4.1 & 2.2 & 1.8 & 8.2 & 4 & 2.2 & 1.4 & 6.9 \\
\hline Lu10 & Lago Verde & & 1.9 & 2.2 & 9.3 & 4.8 & 2.1 & 1.1 & 7.9 & 3 & 1.7 & 1.9 & 3.9 \\
\hline Lu11 & La Junta & 4.1 & 1.6 & 2.4 & 8.1 & 4.3 & & 3 & 7.8 & .7 & 1.9 & 1.6 & .2 \\
\hline Lu12 & Coyhaique & & 1.4 & 2.1 & 7.0 & 4.9 & & & 9.0 & .8 & 1.7 & 1.1 & 6.7 \\
\hline LuP4 & Villarrica & 4. & 1.3 & 1.9 & 7.5 & 3.9 & & 2.6 & 8.8 & 6 & 1.5 & 2.2 & 3 \\
\hline LuP11 & Puerto Saavedra & 4.7 & 1.5 & 2.0 & 8.2 & 4.9 & 2.5 & 2.3 & 9.8 & 5.0 & 1.8 & 2.1 & 8.9 \\
\hline $\mathrm{LuP} 23$ & Vilcún & 5.3 & 1.5 & 1.9 & 8.7 & 4.1 & 2.1 & 1.5 & 7.7 & 4.1 & 2.1 & 0.9 & 7.2 \\
\hline $\mathrm{LuP} 32$ & Liucura & 3.7 & 1.3 & 1.8 & 6.8 & 5.2 & 1.9 & 1.1 & 8.4 & 5.1 & 2.2 & 2.0 & 9.3 \\
\hline LuP36 & Pitrufquén & 4.0 & 1.4 & 1.8 & 7.2 & 4.8 & 2.8 & 1.7 & 9.3 & 3.9 & 2.3 & 1.2 & 7.5 \\
\hline LuP48 & Quellón & 3.7 & 1.9 & 1.6 & 7.2 & 4.7 & 2.1 & 2.9 & 9.8 & 2.6 & 1.8 & 1.8 & 6.3 \\
\hline LuP52 & Castro & 5.1 & 1.4 & 1.6 & 8.1 & 4.8 & 1.7 & 1.1 & 7.5 & 3.2 & 1.9 & 1.2 & 6.4 \\
\hline LuP54 & Castro & 4.2 & 1.6 & 2.0 & 7.8 & 5.3 & 2.3 & 1.9 & 9.6 & 3.3 & 1.9 & 1.9 & 7.2 \\
\hline LuP58 & Puerto Varas & 3.7 & 1.6 & 2.3 & 7.6 & 6.5 & 2.7 & 1.1 & 10.3 & 5.0 & 2.1 & 1.0 & 8.2 \\
\hline LuP63 & Riñihue & 3.9 & 1.4 & 2.3 & 7.6 & 4.9 & 1.9 & 1.2 & 8.0 & 4.1 & 2.5 & 1.1 & 7.7 \\
\hline \multicolumn{2}{|c|}{ s.e.m. } & 0.51 & 0.20 & 0.34 & 0.74 & 0.63 & 0.39 & 0.38 & 0.97 & 1.04 & 0.39 & 0.37 & 1.12 \\
\hline \multicolumn{2}{|c|}{ Significance } & $*$ & $*$ & NS & $*$ & $* *$ & NS & $* *$ & $*$ & NS & $* * *$ & $*$ & $*$ \\
\hline \multicolumn{2}{|c|}{ Mean } & 4.3 & 1.6 & 2.0 & 7.9 & 4.8 & 2.2 & 1.6 & 8.7 & 4.3 & 2.1 & 1.6 & 8.0 \\
\hline
\end{tabular}

s.e.m. $=$ standard error of the mean; $* \mathrm{P}<0.05 ; * * \mathrm{P}<0.01 ; * * * \mathrm{P}<0.001$; NS $=$ not significant.

${ }^{1}$ Control cultivar.

that the consumption of it mixed with legumes that produce meteorism can contribute to correcting this problem (McMahon et al., 1999).

\section{CONCLUSIONS}

The variability in concentrations of $\mathrm{CT}$ observed among the studied cultivars of Lc is high in all of the environments in which the germplasm was evaluated, which allows for identifying genotypes for genetic improvement programs, or making recommendations of cultivars for the zones represented by each of the localities considered in the study.

The germplasm of Lt presented a lower variability in its concentration of CT in the foliage. There were no significant differences between accessions in total CT concentration in any of the environments studied. The values obtained were lower than those of Lc and Lu, but considerable higher than those reported by the literature, which is attributed to the advanced state of maturity of the tissues analyzed, owing to the favorable environmental conditions for the synthesis of these compounds.

The CT concentration in $\mathrm{Lu}$ presented significant differences among accessions in all of the localities, which reflects an important degree of variability in the material studied which permits identifying useful genotypes for improvement programs. These concentrations were greater than those measured in Lc.

\section{ACKNOWLEDGEMENTS}

This study is part of FONDECYT Project 1980003. The authors are grateful for the support of INIA, the Universidad de Concepción and FONDECYT. They are also grateful for the support of Dr. Carlos Lascano, Centro Internacional de Agricultura Tropical (CIAT), Colombia, in the implementation of the analytical methodology. 


\section{Contenido de taninos condensados en germoplasma de tres especies del género Lotus en diferentes ambientes}

\author{
R E S U M E N
}

Los taninos condensados (TC) presentes en Lotus spp., dependiendo de su concentración en la planta, pueden evitar el meteorismo y favorecer la absorción de proteína en rumiantes. Con el objetivo de conocer la variabilidad de esta característica se determinó por el método del butanol-HCl la concentración (\% base materia seca) de TC en 13 cultivares de Lotus corniculatus L. (Lc) introducidos de Norteamérica, Sudamérica y Oceanía, 11 accesiones de Lotus tenuis Waldst. \& Kit. ex Willd. (Lt) y 22 accesiones de Lotus uliginosus Schkuhr. (Lu), colectadas en Chile entre $\operatorname{los} 32^{\circ}$ y $38^{\circ}$ lat. S, y $36^{\circ}$ y $46^{\circ}$ lat. S, respectivamente. Los experimentos, en un diseño de bloques completos al azar con dos repeti- ciones, fueron establecidos en otoño de 1998 en cinco diferentes ambientes en la zona centro sur de Chile (suelo arcilloso, suelo arenoso y tres suelos volcánicos con diferentes niveles de humedad disponible). El muestreo se hizo en primavera-verano de 19992000 , cuando las plantas estaban en plena floración. Se encontraron diferencias significativas entre cultivares o accesiones, dentro de cada localidad, en concentración de TC totales y/o en sus fracciones extractables o ligados a la proteína o a la fibra. Se encontró alta variabilidad entre genotipos de Lc (rango $4,7-8,7 \%$ de TC totales, media $6,1 \%$ ) y de Lu (rango $6,3-11,0 \%$ de TC totales, media 8,2\%). En Lt la variabilidad entre accesiones fue muy baja y la media fue $4,8 \%$ de TC totales, más alta que lo informado por la literatura. Estos resultados contribuirán a la selección de genotipos para programas de mejoramiento genético de estas especies.

Palabras clave: Lotus corniculatus, L. tenuis, L. uliginosus, taninos condensados.

\section{LITERATURE CITED}

Abarca, C.E. 1997. Degradación ruminal in situ de lotera (Lotus corniculatus) cv. Quimey con diferentes tratamientos de altura y frecuencia de corte. $26 \mathrm{p}$. Tesis Ingeniero Agrónomo. Universidad de Concepción, Facultad de Agronomía, Chillán, Chile.

Acuña, H., and G. Cuevas. 1999. Efecto de la altura y frecuencia de la defoliación, bajo corte y pastoreo, en el crecimiento y productividad de tres especies del género Lotus en suelos arcillosos. Agric. Téc. (Chile) 59:296-308.

Acuña, H., M. Figueroa, A. de la Fuente, F. Ortega, y C. Fuentes. 2002a. Comportamiento de cultivares de Lotus corniculatus $\mathrm{L}$. en diferentes ambientes de la VIII y IX Regiones de Chile. Agro-Ciencia 18:75-84.

Acuña, H., M. Figueroa, A. de la Fuente, F. Ortega, I. Seguel, y R. Mundaca. 2002b. Caracterización agronómica de accesiones de Lotus glaber Mill. y Lotus uliginosus Schkur. naturalizadas en Chile. AgroCiencia 18:63-74.

Acuña, H., P. Hellman, L. Barrientos, M. Figueroa, y A. de la Fuente. 2004. Estimación de la fijación de nitrógeno en tres especies del género Lotus por el método de la dilución isotópica. Agro-Ciencia 20:515.

Anuraga, M., P. Duarsa, M.J. Hill, and J.V. Lovett. 1993. Soil moisture and temperature affect condensed tannin concentrations y growth in Lotus corniculatus and Lotus pedunculatus. Aust. J. Agric. Res. 44:16671681.
Arcioni, S., T. Bovone, F. Damiani, and F. Paolocci. 2005. Light intensity is positively correlated with the synthesis of condensed tannins in Lotus corniculatus. p. 244. In O'Mara, F.P., R.J. Wilkins, L. Mannetje, D.K. Lovett, P.A.M. Rogers, T.M. Boland (eds.). XX International Grassland Congress: Offered papers. Dublin, Ireland. 26 June-1 July. Wageningen Academic Publishers, Wageningen, The Netherlands, 2005.

Barry, T. N. 1989. Condensed tannins: their role in ruminant protein and carbohydrate digestion and possible effects upon the rumen ecosystem. p. 153169. In J.V. Nolan, RA. Leng and D. I. Demeyer (eds). The roles of protozoa and fungi in ruminant digestion. Perambul Books, Armidale, Australia.

Barry, T. N., and D. A. Forss. 1983. The condensed tannins content of vegetative Lotus pedunculatus, its regulation by fertilizer application, and effect upon protein solubility. J. Sci. Food Agric. 34:1047-1056.

Burggraaf, V.T., S.L. Woodward, D.R. Woodfield, E.R. Thom, G.C. Waghorn, and P.D. Kemp. 2005. Condensed tannin concentration and herbage accumulation of white clover bred for increased floral condensed tannin. p. 243. In O'Mara, F.P., R.J. Wilkins, L. Mannetje, D.K. Lovett, P.A.M. Rogers, T.M. Boland (eds.). XX International Grassland Congress: Offered papers. Dublin, Ireland. 26 June-1 July. Wageningen Academic Publishers, Wageningen, The Netherlands, 2005. 
Carter, E.B., M.K. Theodorou, and P. Morris. 1999. Responses of Lotus corniculatus to environmental change. 2. Effect of elevated $\mathrm{CO}_{2}$, temperature and drought on tissue digestion in relation to condensed tannin and carbohydrate accumulation. J. Sci. Food Agric. 79:1431-1440.

Douglas, G.B., M. Stienezen, G.C. Waghorn, and A.G. Foote. 1999. Effect of condensed tannins in birdsfoot trefoil (Lotus corniculatus) and sulla (Hedysarum coronarium) on body weight, carcass fat depth, and wool growth of lamb in New Zealand. N.Z. J. Agric. Res. 42:55-64.

Estrella, J.M., y R.A. Ugalde. 1993. Análisis de los flavolanos en especies del género Lotus y su efecto sobre el crecimiento in vitro de Rhizobiun loti. p. 326327. Actas XX Reunión Argentina de Fisiología Vegetal, Chascomus. 25-27 octubre. Instituto de Investigaciones Biotecnológicas-Instituto Tecnológico Chascomús (IIB-INTECH), Buenos Aires, Argentina.

Kelman, W.M. 2006. The interactive effects of phosphorus, sulfur and cultivar on the early growth and condensed tannin content of greater lotus (Lotus uliginosus) and birdsfoot trefoil (Lotus corniculatus). Aust. J. Exp. Agric. 46:53-58.

Kelman, W.M., and G.J. Tanner. 1990. Foliar condensed tannin levels in lotus species growing on limed and unlimed soils in South- Eastern Australia. Proc. N.Z. Grassl. Assoc. 52:51-54.

Lees, G.L., C.F. Hinks, and N.H. Suttill. 1994. Effect of high temperature on condensed tannin accumulation in leaf tissues of big trefoil (Lotus uliginosus Schkur). J. Sci. Food Agric. 65:415-421.

Li, Y-G., G. Tanner, and P. Larkin. 1996. The DMACA$\mathrm{HCl}$ protocol and the threshold proanthocyanidin content for bloat safety in forage legumes. J. Sci. Food Agric. 70:89-101.

Marley, C.L., R. Fychan, and R. Jones. 2006. Yield, persistency and chemical composition of Lotus species and varieties (birdsfoot trefoil and greater birdsfoot trefoil) when harvested for silage in the UK. Grass For. Sci. 61:134-145.

Marshall, A.H., F. Ribaimont, R.P. Collins, D. Bryant, and M.T. Abberton. 2005. Variation in tannin content and morphological traits in Lotus corniculatus L. (birdsfoot trefoil). p. 245. In O'Mara, F.P., R.J. Wilkins, L. Mannetje, D.K. Lovett, P.A.M. Rogers, T.M. Boland (eds.). XX International Grassland Congress: Offered papers. Dublin, Ireland. Wageningen Academic Publishers, Wageningen, The Netherlands.
McMahon, L.R., W. Majak, T.A. McAllister, J.W. Hall, G.A. Jones, J.D. Popp, and K.J. Cheng. 1999. Effect of sainfoin on in vitro digestion of fresh alfalfa and bloat in steers. Can. J. Anim. Sci. 79:203-212.

McMahon, L.R., T.A. McAllister, B.P. Berg, W. Majak, S.N. Acharya, J.D. Popp, et al. 2000. A review of the effects of forage condensed tannins on ruminal fermentation and bloat in grazing cattle. Can. J. Plant Sci. 80:469-485.

Miller, P.R., and N.J. Ehlke. 1996. Condensed tannins in birdsfoot trefoil: genetic relationships with forage yield and quality in NC-83 germplasm. Euphytica 92:383-391.

Strittmatter, C.D., R.A. Ricco, M. Kade, M. Wagner, and A.A. Gurni. 1994. Condensed tannins in Lotus tenuis Waldst. et Kit. Lotus Newsl. 25:41-44.

Tanner, G.J., P.J. Moate, L.H. Davis, R.H. Laby, I.G. Li, and P.J. Larkin. 1995. Proanthocyanidins (condensed tannins) destabilize plant protein foams in a dose dependant manner. Aust. J. Agric. Res. 46:1101-1109.

Terrill, T.H., A.M. Rowan, G.B. Douglas, and T.N. Barry. 1992. Determination of extractable and bound condensed tannins concentration in forage plants, protein concentrate meals and cereal grains. J. Sci. Food Agric. 58:321-329.

Terrill, T.H., W.R. Windham, and J.J. Evans, and C.S. Hoveland. 1990. Condensed tannins concentration in Sericea lespedeza as influenced by preservation method. Crop Sci. 30:219-224.

USDA. 1994. Reference to soil taxonomy. United States Department of Agriculture (USDA), Washington, D.C.

Waghorn, G.C., W.T. Jones, I.D. Shelton, and W.C. McNabb. 1990. Condensed tannins and the nutritive value of herbage. Proc. N.Z. Grassl. Assoc. 51:171176.

Wang, Y., G.C. Waghorn, W.C. McNabb, T.N. Barry, M.J. Hedley, and I.D. Shelton. 1996. Effect of condensed tannins in Lotus corniculatus upon the digestion of methionine and cysteine in the small intestine of sheep. J. Agric. Sci. 127:413-421. 